Barbara Gerke*

\title{
Biographies and Knowledge Transmission of Mercury Processing in Twentieth Century Tibet
}

DOI 10.1515/asia-2015-1041

Abstract: The processing of metallic mercury into the form of a mercury sulphide ash, called tsotel (btso thal), is considered the most refined pharmacological technique known in Tibetan medicine. This ash provides the base material for many of the popular "precious pills" (rin chen ril bu), which are considered essential by Tibetan physicians to treat severe diseases. Making tsotel and precious pills in Tibet's past were rare and expensive events. The Chinese take-over of Tibet in the 1950s, followed by the successive reforms, including the Cultural Revolution (1966-1976), affected the opportunities to transmit the knowledge and practice of making tsotel. In this article, I discuss two Tibetan physicians, Tenzin Chödrak (1924-2001) and Troru Tsenam (19262004), both of whom spent many years in Chinese prisons and labour camps, and their role in the transmission of the tsotel practice in a labour camp in 1977, contextualising these events with tsotel practices in Central and South Tibet in preceding decades. Based on two contemporary biographies, their descriptions of making tsotel will be analysed as well as the ways in which the biographies depicted these events. I argue that the ways of writing about these tsotel events in the physicians' biographies, while silencing certain lines of knowledge transmission, established an authoritative lineage of this practice. Both physicians had a decisive impact on the continuation of the lineage and the manufacturing of tsotel and precious pills from the 1980s onwards in both India and the People's Republic of China (PRC).

Keywords: Mercury processing, Tibetan medicine, Cultural Revolution, Troru Tsenam, Tenzin Chödrak, knowledge transmission, biographies (rnam thar), history, chronicle (lo rgyud), twentieth-century Lhasa, twentieth-century Tibet

\footnotetext{
*Corresponding author: Barbara Gerke, Humboldt Universität zu Berlin, Institut für Asien- und Afrikawissenschaften, Zentralasien-Seminar, Unter den Linden 6, 10099 Berlin, Germany. E-mail: barb_gerke@yahoo.co.uk
} 
"We now know that narratives are made of silences, not all of which are deliberate or even perceptible as such within the time of their production.

We also know that the present is itself no clearer than the past".

Michel-Rolph Trouillot, Silencing the Past: Power and the Production of History

\section{Introduction: Tsotel and some historical trajectories}

Mercury, the shiny liquid and highly toxic element, has been used in medical preparations across Asia for a very long time, especially in Ayurveda ${ }^{1}$ and Chinese medicine. ${ }^{2}$ Knowledge of various mercury processing methods reached Tibet mainly from India, ${ }^{3}$ and in some cases also from China. ${ }^{4}$ While simpler forms of mercury processing are described in earlier Tibetan medical texts, the beginnings of more complex mercury processing practices date to the thirteenth century $\mathrm{AD}$, and apparently came from in the Swat Valley of what is now Pakistan. The most complex practices are said to have been brought to Tibet by Orgyenpa Rinchenpel (O rgyan pa Rin chen dpal, 1229/30-1309). They were refined and transmitted through various medical and Buddhist schools and developed into a sophisticated technique of processing mercury, sulphur, eight other metals, eight mineral or rock substances, and numerous herbs. The final product is a "detoxified" mercury sulphide compound, called "cooked ash" or tsotel (btso thal). ${ }^{5}$ This ash compound is added in varied amounts to some of the "precious pills" (rin chen ril bu). Medical practitioners in Eastern Tibet promoted particular techniques of making tsotel through their medical schools and lineages over several centuries, while others were established in Central Tibet under and since the Fifth Dalai Lama in the seventeenth century. ${ }^{6}$ When referring to "tsotel events" in this paper, I mean the entire processing procedure required to arrive at the final ash product, tsotel.

Apart from tsotel, precious pills also contain precious stones and other elaborate mineral and herbal ingredients, some of which are considered sacred. They are difficult and time-consuming to produce and historically required wealthy sponsors, either from the local ruling elite, the aristocracy, or influential

1 See, for example, Wujastyk 2013 on the history of mercury in Sanskrit medical texts.

2 See, for example, Needham et al. 1976.

3 Czaja 2013; Simioli 2013.

4 Gerke 2015.

5 See Gerke 2013 for a social biography of tsotel.

6 Czaja 2013. 
heads of monasteries. Precious pills hold the status of being the strongest and most important medicines in the Tibetan pharmacopeia. These pills are manufactured to this day in Tibetan areas of the PRC and in Tibetan pharmacies in India and are considered the pinnacle of Tibetan pharmacology. ${ }^{7}$ At the same time they are controversial because of their mercury content.

This paper presents and discusses mercury processing events in Tibet between 1919 and 1977, during which Tibetan physicians manufactured tsotel and also some types of precious pills. These events will be placed in their sociopolitical context, highlighting aspects that contributed to this practice being performed very rarely and almost becoming extinct. Two Tibetan physicians, Tenzin Chödrak (Bstan 'dzin chos grags, 1924-2001) ${ }^{8}$ and Troru Tsenam (19262004), ${ }^{9}$ both of whom spent many years in Chinese prisons and communist labour camps, played a fundamental role in the survival of this pharmacological knowledge and its transmission into the twenty-first century.

The narratives are sourced from two modern biographies on these two physicians that were recently written in Tibetan, one in India and one in the PRC. Based on these biographies, descriptions of Tenzin Chödrak making tsotel in 1953 in Phagri (Phag ri), Southern Tibet, and Tenzin Chödrak making tsotel together with Troru Tsenam in 1977 at the labour camp of Powo Tramo (Spo bo Kra mog) in Eastern Tibet, will be analysed. Tenzin Chödrak later transmitted this practice to Tibetan physicians in India and Troru Tsenam to physicians in Tibetan pharmacies in the PRC. My analysis will focus on two aspects: first, the kinds of knowledge transmission involved in mercury processing and second, the ways in which mercury processing and its knowledge transmissions are depicted in these biographies and what this tells us about Tibetan biographical writing.

The focus on these particular places does not imply that mercury was not processed in other places. The documentation of tsotel practices outside institutional settings is quite sporadic and not yet researched, and this article presents preliminary data on what we know about medical mercury processing by Tibetan doctors of the twentieth century, who at some point in their medical careers were related to the main medical institutions in Lhasa. The history of mercury processing in Eastern Tibet (Kham) was transmitted through the Drigung Kagyüpa school ('Bri gung Bka' brgyud pa) and representatives of

7 Gerke 2013, Kloos 2012.

8 Several other sources mention 1922 or 1923 as his year of birth. 1924, the wood-mouse year of the fifteenth Tibetan Rabjung, is based on the biography by Sonam Rinchen 2000: 39.

9 These dates are according to Lozang Lodrö 2006: 8, 276. Holmes 1995: 144 mentions 1928 as his year of birth; Chödrak/van Grasdorff 1999: 117 mention 1923. 
the Rimé movement, who were very active in the nineteenth century and produced a large amount of literature on the topic. ${ }^{10}$ After political relaxations in the 1980s, Troru Tsenam processed mercury and made precious pills many times, largely in Eastern Tibet, but this period of mercury processing still needs to be researched. There were also privately practising family lineage amchis, ${ }^{11}$ who with the help of local Buddhist monastic leaders made tsotel and even involved female amchis in mercury processing. Most Tibetan pharmacologists and institutions do not permit women to process mercury to this day, proclaiming that it is contrary to the secret oral tradition and would negatively affect mercury's process of alchemical transformation. ${ }^{12}$ Nevertheless, there are examples of women making tsotel. One is a nun called Ani Ngawang (A ni Ngag dbang) in Nyemo (Snye mo) County, who prepared an eye medication that apparently contained self-made tsotel. $^{13}$ This is probably the same Ani Ngawang who, according to Sonam Rinchen, in the 1970s pointed the Tibetan physician who was searching for surviving tsotel specialists to the imprisoned Tenzin Chödrak, a story told later in this paper.

Learning medicine relates to "styles of knowing" and to how knowledge is transmitted. ${ }^{14}$ Ways of transmitting the knowledge of mercury processing are very complex and involve several forms of pharmacological knowledge transmission, such as "empowerments/initiations" or wang (dbang), "oral transmission" known as lung (lung), "explanations" on the actual practice called tri (khrid), as well as the "seeing transmission" briefly called thongyü (mthong ba rgyud pa'i phyag bzhes, lit. "hands-on instruction through seeing transmission"), "practical instructions" or laglen (lag len dmar khrid; lit. "essential instructions on practical procedures"), and "secret oral instructions" or men ngak (man ngag), all explained in the next section. As will become clear, the ways in which these kinds of knowledge transmissions are mentioned or kept silent in the modern biographies have specific effects on the (re)construction of the authoritative lineage of tsotel transmissions. First, these various ways of transmitting medical, and specifically pharmacological, knowledge will be discussed.

10 See Czaja 2013 on the history of mercury practices and related literature. Mercury processing practices in Amdo have not yet been researched.

11 Amchi is a Mongolian derived term for Tibetan physician.

12 See, for example, Dawa Ridak 2003: 427. Sonam Rinchen 2000: 106.

13 Fjeld/Hofer 2010-2011: 186; Hofer in preparation.

14 See Hsu 1999 on styles of knowing in Chinese medical contexts. 


\section{Tibetan ways of transmitting medical knowledge}

There are several approaches to transmitting knowledge in Tibetan societies. These are deeply embedded in Tibetan "traditions", known as solgyün (srol rgyun, lit. "continuation of customs"), and involve various concepts and practices, such as the accumulation of merit, practical experience, as well as power and authority through a lineage that is passed on from teacher to disciple. The three most widely-known aspects of knowledge transmission in Tibetan societies are: Spiritual empowerments or wang given by a highly qualified teacher or lama; oral transmission or lung, which involves the oral transmission of reading the text that is to be studied out loud; and oral instructions on the actual practice called tri. In the words of a contemporary amchi: "In our culture, these three things-wang, lung, tri-mean that you have been granted permission to practice. If wang is not received, this means you have no authority. And when there is no authority, I don't think we have the power to put our skills into practice". ${ }^{15}$ Moreover, the "secret oral instructions" are essential for learning how to make medicines and to diagnose illness. Since making medicines involves hands-on experience-observing through the senses how things are done-the "seeing transmission" is essential. Involving the sense organs links up with spiritual practices in Tibetan Buddhism, collectively known as "liberation through the senses", where liberation is experienced through contact with sacred things through the sense organs, e.g. "hearing" the reciting of sacred texts, "seeing" holy relics, "touching" sacred objects, or "eating" sacred letters. ${ }^{16}$

In pharmacology, the "seeing transmission" is considered absolutely essential; it also involves spiritual practices. ${ }^{17}$ In the words of a senior Tibetan physician from Lhasa, commenting on mercury processing:

If we can master the stainless practice of the Great Mercury Processing (dngul chu btso bkru chen $\mathrm{mo}$ ) through the 'seeing transmission', it can help us temporarily remove all the diseases, and ultimately it can help us to attain the supreme state of omniscience. ... You need the practice of 'seeing transmission', no matter how much we talk, it won't be of much benefit. ... Even if we give three months lessons, talking through the steps of the practice of the Great Mercury Processing, there won't be a result without the 'seeing transmission'. ${ }^{18}$

15 Recorded during a Tibetan medicine workshop in Kathmandu, 06.12.2011.

16 Tokarska-Bakir 2000. See Garrett 2009 on eating Tibetan letters.

17 See Gerke in press on ritualised pharmacology.

18 Recorded during a Tibetan medicine workshop in Kathmandu, 06.12.2011. 
We can thus understand that whenever a medical institute, a group of doctors, or a monastery made tsotel, it was an opportunity to pass on all forms of knowledge transmission described above, especially the "seeing transmission," to the next generation of physicians.

When talking about "seeing transmission" we need to consider that most knowledge transmissions go beyond a textual understanding. In a culture in which oral recitation is key to learning, and texts function more as mnemonic devices than as all-inclusive textbooks, texts are often written in incomplete phrases that adhere to a rhythmic poetic style and certain syllables (and medical details) are intentionally left out. ${ }^{19}$ Reading texts is one aspect of knowledge transmission, memorising them another, understanding them a third, and realising their secret meaning a fourth. A complete transmission of medical knowledge would therefore be complex and involve wang, lung, tri, thongyü, laglen, and men ngak in the long process of accomplishing a practice. The objective is to uphold a comprehensive lineage of a practice across many generations. As will become clear, in medical biographies certain knowledge transmissions are (un) intentionally and variedly emphasised and sometimes even kept silent. In effect, they create "authoritative lineages" for the present rather than report "historical facts" of the past.

\section{Reading modern biographies as sources on the history of mercury processing}

Historical events are tricky to trace, and a view of history "as a combination of fact and meaning”, 20 to quote Carol McGranahan, certainly helps to understand the hagiographies of tsotel events. These are shaped by attempts to-often retrospectively-(re)shape, install, and decree certain lines of knowledge transmission that are linked to charismatic accomplished physicians, who through their biographies are installed as official representatives of an authoritative lineage. For Tibetans, they are extremely important to this day, since they assign a certain authenticity to a medical practice, and to understand this it is good to remember that "historical authenticity resides not in the fidelity to an alleged past but in an honesty vis-a-vis the present as it re-presents that past". ${ }^{21}$

19 See Gerke 2012.

20 McGranahan 2002: 113.

21 Trouillot 1995: 149. 
In the following, I briefly analyse how the sources I use to trace tsotel events in twentieth century Tibet have been written under the influence of related political and social events as well as personal choice, which is often difficult to trace. For example, from reading the biographies of Tenzin Chödrak and Troru Tsenam it is almost impossible to tell who of the two physicians was the most instrumental in making tsotel at the Powo Tramo labour camp in 1977. Both biographies acknowledge the other merely by name while presenting its subject as the main actor of the event. Both publications thus emphasise the high position of their teacher for their respective reader clientele: Tibetan medical communities in India and in the PRC, respectively. I argue that by the ways in which these two biographies are presented, they fulfil the purpose to re-establish an authoritative lineage holder of tsotel practices in the PRC and in India, even though they do not necessarily acknowledge the ways in which medical knowledge was transmitted.

There are principally two types of literary categories pertaining to Tibetan (auto)biographies: First, the historical account labelled logyu (lo rgyus), which is a chronicle of past events; Second, religious biographies exclusively about ordained individuals, known as namthar (rnam thar, lit. 'complete liberation'), or, in the case of autobiographies, rangnam (rang rnam, lit. 'one's own full [liberation]'). Henrion-Dourcy translates the latter two as "hagiographies," and defines them as "didactic tales for religious edification and inspiration," "where history and myth are not separate conceptual categories," 22 thus acknowledging their heterogeneous nature. Modern post-1950s Tibetan autobiographies written in the PRC and in exile show "different aspirations," and often have a political purpose, ${ }^{23}$ thus becoming "performances rather than literary texts". ${ }^{24}$ Henrion-Dourcy therefore classifies these as a type of logyu.

As a Tibetan religious form of biography, the namthar presents the life of the person from birth to death, narrating events of particular religious significance. ${ }^{25}$ Namthars have often been criticised from a Western historiographical point of view for their subjective statements, overemphasising miracles, supernatural experiences, auspicious dreams, and glorifying the lives of the masters. Nevertheless, they are the literary source of much of what we know about Tibetan figures of the past, and should be read keeping their character in

22 Henrion-Dourcy 2013: 207.

23 Henrion-Dourcy 2013: 207-208.

24 Henrion-Dourcy 2013: 228.

25 On the structure of namthars see Vostrikov 1970: 187ff. 
mind. ${ }^{26}$ That a namthar is often more concerned with how the community wishes to remember the person than with recording details of the life itself, has been demonstrated well by Holmes-Tagchungpa (2014) with the biography of Tokden Shakya Shri.

In the case of physicians, a biography typically includes the names of teachers, the texts studied, the lineages and transmissions received, the names of their students, as well as specific pharmacological achievements, such as the making of tsotel or precious pills. However, not mentioning such pharmacological events does not mean they did not take place. For example, while Orgyenpa Rinchenpel is considered the father of Tibetan mercury processing and translated and wrote several treatises on mercury, ${ }^{27}$ none of his eleven existing namthars mentions him actually processing mercury on any scale. ${ }^{28}$ Only one biography mentions that Orgyenpa Rinchenpel told Kublai Khan during his visit to the capital of Yuan in 1293 that he knew how to turn mercury into silver, from which we infer that he knew how to process mercury. ${ }^{29}$

The two biographies discussed here show characteristics of both literary categories, namthar and logyu. Troru Tsenam's biography is labelled a namthar since he was an ordained monk and an accomplished "great scholar" (mkhan chen). ${ }^{30}$ Tenzin Chödrak's biography is a modern logyu. Nevertheless, the terms namthar and logyu are used interchangeably in his biography as well as by the author during our conversations, which shows that the genres of namthar and logyu in day-to-day usage often overlap. As will become clear, both biographies also have performative purposes.

When dealing with biographies we also have to consider the relationship of the authors with the subject of their writing, and the political climate they lived and wrote in. ${ }^{31}$ The two authors we are concerned with here are, first, Lappendum Lozang Lodrö (Lab phan 'dum Blo bzang blo gros, born 1958 in Quinghai Province), a researcher at the China Tibetological Research Centre, who studied grammar with Troru Tsenam for two years. The biography was

26 On the nature of namthars and rangnam see for example, Covill et al. (eds.) 2010; Gyatso 1998; Holmes-Tagchungdarpa 2014; Henrion-Dourcy 2013; Penny (ed.) 2002; Jacoby 2014; Willis 2009.

27 He is said to have translated two Sanskrit treatises into Tibetan that were included in the Tibetan Buddhist Canon and is also attributed with the authorship of a text on mercury processing. See Simioli 2013.

28 Li 2011. Personal communication, Brenda Li and Olaf Czaja, 2012.

29 Sonam Oeser 1997: 239. Thanks to Brenda Li for this reference.

30 Lozang Lodrö 2006.

31 Gyatso 1998: 103-105 describes the "fuzzy border" between biography and autobiography and the overlaps in authorship between subject and disciple. 
written posthumously, in the third person, and reflects Lozang Lodrö's admiration for his teacher. The second author, E pa Sonam Rinchen (E pa Bsod nams rin chen, born 1974 in Lhokha, TAR), escaped to India in 1994, and was fully trained in both medicine and astrology at the Men-Tsee-Khang in Dharamsala. ${ }^{32}$ He was Tenzin Chödrak's medical student; they both had mutual friends in Lhokha and shared the experience of being "new arrivals" (gsar 'byor ba) in Dharamsala. In the early 1990s, the Men-Tsee-Khang published a book with the biographies of Khyenrab Norbu (Mkhyen rab nor bu, 1883-1962), ${ }^{33}$ who founded the Mentsikhang ${ }^{34}$ in Lhasa in 1916, and of his two students Tenzin Chödrak and Lozang Wangyal (Blo bzang dbang rgyal), who spent their later lives in Dharamsala. By publishing these three biographies together, the Dharamsala Men-Tsee-Khang portrays its regional connection with the Dalai Lamas and with the Lhasa Mentsikhang back in Tibet.

In 1990, the famous physician Jampa Trinle (1928-2011), then head of the Lhasa Mentsikhang, published A Collection of Namthars of Tibetan Physicians in Chronological Order in Beijing, which was also printed in Dharamsala in 1991. Jampa Trinlés book did not-and for obvious political reasons could notinclude biographies of Tibetan physicians related to the Dalai Lama in exile. ${ }^{35}$ The Men-Tsee-Khang biographies project was apparently not a conscious response to this publication, ${ }^{36}$ but was based on the director's idea to record the lives of the two still-living senior physicians in exile-Tenzin Chödrak and Lozang Wangyal-and their teacher back in Lhasa-Khyenrab Norbu. ${ }^{37}$

Tenzin Chödrak at first declined requests to be interviewed, reflecting a common Tibetan sentiment of self-depreciation, often found in namthars. ${ }^{38}$ Sonam Rinchen was eventually successful in interviewing Tenzin Chödrak regularly over three years. Having common friends helped him gain Tenzin

32 Sonam Rinchen 2000, 2009. For his biography see: http://www.palpung.org.nz/dr-aepasonam-rinchen-bio.php (last accessed April 15, 2015).

33 See Tashi Tsering 2015 on recent biographical notes on Khyenrab Norbu.

34 The spelling of the two institutes follows contemporary convention: Mentsikhang for Lhasa and Men-Tsee-Khang for Dharamsala in Indian exile.

35 See Hofer 2011: 112-115 for a critical analysis of this collection of namthars. Hofer concludes that apart from mentioning events during the Cultural Revolution, in this collection there is a “complete lack of details concerning the period from 1959 to 1976”. Hofer 2011: 114.

36 Personal communication, Tashi Tsering, Dharamsala, India, July 2014.

37 Interview with Sonam Rinchen, Sherabling, India, 2.7.2014. See also Sonam Rinchen 2000: 337-342 on the process of writing the book. An abbreviated version of Tenzin Chödrak's biography also appeared in Sonam Rinchen's collection of essays (2009).

38 Gyatso 1998: 106. 
Chödrak's trust. ${ }^{39}$ Most sections of the biography are based on these interviews and were written in first person, again not unusual for namthars. ${ }^{40}$ Other biographies of Tenzin Chödrak published in English, French, and German ${ }^{41}$ appeared before or in connection with Franz Reichle's Film "The Knowledge of Healing” (Reichle 1995), which prominently features Tenzin Chödrak. Shorter biographies of Troru Tsenam were included in his publications on Tibetan medicine, ${ }^{42}$ or published separately, ${ }^{43}$ also in English. ${ }^{44}$ Apart from these sources, I consulted modern sources in Tibetan on mercury processing events, ${ }^{45}$ on tsotel lineages, ${ }^{46}$ and a brief history of Chakpori, the Tibetan medical college in Lhasa that existed from 1696 to $1959 .{ }^{47}$

In the following, I lay out the history of mercury processing in Lhasa at the beginning of the twentieth century. This is important background information to understand the later transmissions of the tsotel practice and their representation in the two biographies.

\section{Making tsotel in Lhasa during the first half of the twentieth century}

In the early twentieth century, tsotel was prepared twice within three years in Lhasa under the auspices of the Thirteenth Dalai Lama Thubten Gyatso (Thub bstan rGya mtsho, 1876-1933) and his most senior personal physician Trekhang Jampa Thubwang (Bkras khang Byams pa thub dbang, ca. 1863-1922), a monk of aristocratic background. The close succession of these two events of 1919 and 1921 is particularly noteworthy, given the otherwise seemingly sporadic sequence of tsotel making in Central Tibet. ${ }^{48}$ The last major documented tsotel event in Lhasa had taken place in 1893, also initiated by the Thirteenth Dalai

39 Interview with Sonam Rinchen, Sherabling, India, 2.7.2014.

40 Gyatso 1998: 103.

41 Avedon 1997; Chödrak 1994, 2005; Chödrak/van Grasdorff 1999, 2000.

42 Troru Tsenam Vol. 1, 2001: 1-19.

43 Thubten Phuntsok 1994. Thanks to Tashi Tsering for providing a copy of this namthar.

44 Holmes 1995.

45 Dawa Ridak 2003: 402-412.

46 Sonam Bakdrö 2006: 22-57.

47 Thubten Tsering 1986 in Gerl/Aschoff 2005: 22-78.

48 These events might also be mentioned in the Thirteenth Dalai Lama's biography, which I was unable to check. 
Lama, who at the time invited the physician Orgyen Tenzin (O rgyan bstan 'dzin) to make tsotel in Lhasa. ${ }^{49}$ Jampa Thubwang and others were trained on this occasion.

In 1919, both the Thirteenth Dalai Lama and Jampa Thubwang oversaw the making of tsotel in Lhasa. According to some accounts, the lineage and technical skills were passed on to Khyenrab Norbu and others. ${ }^{50}$ At the time, several kinds of precious pills were manufactured: Rinchen Mangjor Chenmo, Wangril 25, Rinchen Tsodru Dashel, Drangjor Rilnag Chenmo, and others. ${ }^{51}$

Precious pills were and still are not only considered necessary to treat severe diseases, but are also attributed with the magical potency of protecting against spirits, enemies, and poisoning. ${ }^{52}$ Moreover, they hold "political efficacy", in that they are used as gifts to high-ranking officials and wealthy patrons, who often sponsor the expensive, labour-intensive, and time-consuming manufacturing process. The Tibetan government itself sponsored the making of tsotel and precious pills several times throughout its history. ${ }^{53}$

In 1921, Jampa Thubwang made tsotel at the Norbulingka Palace, the summer residence of the Dalai Lama. ${ }^{54}$ During the burning of metals an explosion occurred, which is described by Jampa Trinlé in his brief namthar of Jampa Thubwang. This is the only detailed description of the event, which is sometimes overemphasised. ${ }^{55}$ Jampa Trinlé writes:

In the Iron Bird year (1921), the high monk official Trekhang (Bkras khang) [i.e. Jampa Thubwang] himself was leading the manufacturing of tsotel at the Norbulingka. At that time, his personal students, the court physician Khyenrab Norbu, Tsultrim Gyaltsen (Tshul khrim rgyal mtshan) from Chakpori, ${ }^{56}$ Namgyal (Rnam rgyal), and Tsoknyi-la (Tshogs gnyis lags), were present. Besides them, being both attendants and medical students were Lhalu Korpa (Lha glu skor pa) and Rindzin Lhundrup (Rig 'dzin lhun grub, 1889-1986), who is Nyarongshag's (Nang rong shag) teacher, and others. ${ }^{57}$ He [Jampa Thubwang] taught the

49 Dawa Ridak 2003: 410. This is probably Lhamen Orgyen Tenzin Gyasto (Bla sman O rgyan bstan 'dzin rgya mtsho), but Jampa Trinlé's biography of him does not mention any tsotel event. 50 Dawa Ridak 2003: 411. Sonam Bakdrö 2006: 47.

51 Dawa Ridak 2003: 410. Sonam Bakdrö 2006: 47.

52 Czaja 2013.

53 Dawa Ridak 2003: 410 mentions several such events, for example in 1754 and 1893.

54 Dawa Ridak 2003: 410. Jampa Trinlé states that the Dalai Lama co-financed the event through the state treasury office. Jampa Trinlé 1991: 420 and 2000: 434.

55 Pasang Yonten Arya, personal communication through Theresia Hofer, July 2014.

56 For his biography see Jampa Trinlé 2000: 525-532.

57 Similar lists of names are mentioned in Pasang Yontan Arya 1988: 177-178 and Choelothar 2000: 23 . 
entire 'seeing transmission and practical procedures' (mthong brgyud lag len) without keeping any secrets. At that time, one day when they were preparing gold ash (gser thal), they were not able to seal well the clay container that they were using. There was an explosion, and the clay jug was scattered into the sky and [pieces] fell in the middle of the Norling [performance] stage. The Thirteenth Dalai Lama said they should experiment again, and asked for more gold, etc., from the state treasury office (rtse phyag las khung) to provide materials for doing it again, and thus he gave them confidence. Nyerongshag's teacher Rindzin Lhundrup told me about all this. ${ }^{58}$

Following that, but no date is mentioned, Khyenrab Norbu along with his private student Kunga Phuntsog (Kun dga' phun tshogs) and others, apparently made tsotel for a wealthy monk aristocrat of the Changra House in the Ramoche area of Lhasa (Ra mo che lcang ra), who "needed processed mercury". 59 Unfortunately, no sources or details are given, but this brief excerpt tells us that in the 1920s in Lhasa rich individuals were in the position to request Tibetan physicians to make tsotel for them, something that has been described for earlier centuries as well. ${ }^{60}$

How can we understand these closely related tsotel events of 1919 and 1921 in Lhasa? They fall within a time in Central Tibetan history that was marked by state health reforms and an increasing interest in public healthcare, in which both the Thirteenth Dalai Lama and Jampa Thubwang had been active for some time. They had established the Mentsikhang and a post-natal child-care programme, both in $1916 .{ }^{61}$ The importance of having access to precious pills during the health reforms of 1916-1924 might have played a role in organising and procuring sponsors and governmental patronage for these two tsotel events. ${ }^{62}$ During this time, funds flowed from various sources into the development of Tibetan medicine, its public health programme, vaccination, education, and also the renovation of the old Chakpori medical school, which had been established in 1696 on the Iron Hill opposite the Potala. ${ }^{63}$ Such financial and material support for Tibetan medical activities declined after 1923/1925, apparently due

58 My translation of Jampa Trinlé 1991: 420. Thanks to Theresia Hofer for pointing me to this reference and sharing an earlier draft translation of the section.

59 This is only mentioned by Dawa Ridak 2003: 411.

60 Czaja 2013: 93-94.

61 Van Vleet 2010-2011: 353-354.

62 Dawa Ridak also contextualises the 1921 tsotel event within the childcare programme of the Thirteenth Dalai Lama and the establishment of the new Mentsikhang in Lhasa, listing the event as one of the numerous activities by the Thirteenth Dalai Lama to support Tibetan medicine (Ridak 2003: 410).

63 For details on these renovations see Thubten Tsering 1986: 153, 178, in Gerl/Aschoff 2005: 27,59 . 
to internal conflicts and personnel problems within Chakpori. ${ }^{64}$ This led to a split between the two medical institutions, Chakpori and the Mentsikhang, with Khyenrab Norbu being replaced as head of Chakpori in $1924,{ }^{65}$ but remaining in charge of the Mentsikhang. ${ }^{66}$ The public health program declined, and between 1924 and 1950 the Mentsikhang only received irregular financial support from the government. ${ }^{67}$

Surprisingly, Thubten Tsering, the last director of Chakpori, does not mention the two tsotel events of 1919 and 1921 in his historical account of the medical college, even though teachers from Chakpori were involved. Later, a request was made by the Chakpori community to Khyenrab Norbu to arrange for the preparation of two types of precious pills, Rinchen Drangjor Chenmo and Ratna Samphel, at Chakpori. Since this narrative is sequenced right after his report on improvements at Chakpori with newly appointed teachers in 1950 and 1956, ${ }^{68}$ the request could have been made after Khyenrab Norbu received two kilograms of tsotel from the processing in Phagri in 1953 or it could refer to Jampa Trinlés record of making Ratna Samphel in 1963 (see section below).

Although Khyenrab Norbu received the "seeing transmission" and was present during the two preparations of tsotel (and perhaps made it at Ramoche), he did not practise it after the 1921 accident. ${ }^{69}$ The reasons for this remain unclear. Maybe the death of Jampa Thubwang in 1922 played a role; maybe the experience of the explosion instilled some insecurity in the pharmacological methods used; maybe patronage and funds could not be procured. We know that after 1924 governmental support to the Mentsikhang was rather irregular, and Khyenrab Norbu had to inventively rely on outside sponsors, trading medicines for wool, and selling calendars to finance the Mentsikhang. ${ }^{70}$ Whatever the reasons, officially no more tsotel was prepared at the medical institutions of Lhasa after 1921, for decades to come, until 1953. ${ }^{71}$

64 Thubten Tsering 1986: 179, in Gerl/Aschoff 2005: 53, 77.

65 Choelothar 2000: 30.

66 Kloos 2010: 65.

67 Van Vleet 2010-2011: 371. See also Janes 1995.

68 Thubten Tsering 1986: 179-180, in Gerl/Aschoff 2005: 53-54, 76-77.

69 Personal communication, Choelothar, Dharamsala, 2012.

70 Van Vleet 2010-2011: 371.

71 Sonam Bakdrö 2006: 48, 57 mentions a tsotel manufacturing event in Eastern Tibet in 1933 under Jamyang Chökyi Lodrö ('Jam dbyangs chos kyi blo gros, 1893-1959) and Kesip Atsang (Ke srib A tshang). There might have been other tsotel events in different Tibetan regions that are not recorded in physicians' biographies but are mentioned in other texts. 
Tenzin Chödrak enters the stage of mercury processing in 1953. A short summary of his life will help to contextualise the following tsotel events. Tenzin Chödrak was born in 1924 in Nyemo near Lhasa and became a medical student in Lhasa in 1940, aged seventeen. He was a monk of the Bodong school (Bo dong) and was trained by Khyenrab Norbu at the Lhasa Mentsikhang. Tenzin Chödrak's studies included eight years of pharmacology training. He graduated in 1952 and eventually became the personal physician, first of the Dalai Lama's mother and then of the Fourteenth Dalai Lama himself. In 1953, he was sent by Khyenrab Norbu to make tsotel in Phagri (see next section). In 1959, he was imprisoned and spent about two decades in Chinese prisons and various labour camps, undergoing forced "re-education". ${ }^{72}$ His life and ordeals are described in some of his books and his "autobiographies,"73 published in several languages.

By the mid-1970s, after he cured a Chinese officer, he was allowed to practise medicine. In 1977, he, together with Troru Tsenam, made tsotel at Powo Tramo (described in the second half of this paper). In 1980, Tenzin Chödrak was permitted to enter India, where in 1982 he oversaw the making of tsotel at the Men-Tsee-Khang in Dharamsala for the first time since its establishment in $1961{ }^{74}$ Under the harsh refugee circumstances, it was initially very difficult for Tibetans to make tsotel in exile. Before 1982, they made very few precious pills (Yunying 25, Jumar 25, Mangjor Chenmo), all of which were produced without tsotel $^{75}$ Tenzin Chödrak passed away in Dharamsala in 2001 at the age of seventy-seven.

72 His statement on his imprisonment before the Subcommittee on International Operations and Human Rights of the Committee on International Relations, United States House of Representatives, is available online: http://archive.org/stream/victimsoftorture00unit/victim softorture00unit_djvu.txt (last accessed May 10, 2015).

73 Avedon 1997; Chödrak 1994; Chödrak/van Grasdorff 1999, 2000; Sonam Rinchen 2000, 2009. Note that even though some of these books are presented as autobiographies and are written in the first person, none of them were written by Tenzin Chödrak himself. For example, Chödrak/van Grasdorff 1999, 2000 is written in the first person and mentions Tenzin Chödrak as the author. The book is, however, based on interviews with simultaneous translations involving several interpreters and writers, and is thus strictly speaking not an autobiography.

74 See Men-Tsee-Khang 2011: 5-6 on six tsotel events in Dharamsala between 1982 and 2011. 75 Pema Dorjé, personal communication, July 2014. Note that Yunying 25 is still made without tsotel, Mangjor Chenmo now has tsotel, and Jumar 25 does not contain tsotel but is coated with cinnabar. 


\section{Making tsotel in Phagri, Southern Tibet, 1953}

In the water-snake year of $1953,{ }^{76}$ Khyenrab Norbu sent his promising medical student, Tenzin Chödrak, to Phagri Richung Phatok, ${ }^{77}$ south-west of Lhasa, a high altitude settlement close to the Bhutan and Sikkim borders, to make tsotel with Palden Gyaltsen (Dpal ldan rgyal mtshan, birth date unknown, died around 1972 in Sikkim), who was Chödrak's senior student colleague. Palden Gyaltsen taught medicine near Phagri in a medical school called Richung Potok Riteng (Ri chung po tog ri steng Sman rtsis khang), and had eight medical students. ${ }^{78}$ Having such a student work force might have provided an additional incentive to make tsotel in Phagri. ${ }^{79}$

Tenzin Chödrak had just graduated as the best student in his batch with the kachupa (bka bcu pa) degree of medicine. ${ }^{80}$ Perhaps his good marks, but surely also his skills in practical pharmacology, especially with burning metal ashes, ${ }^{81}$ made Khyenrab Norbu choose him for the Phagri tsotel event, which has a rather bizarre background story, the details of which I was unable to confirm: ${ }^{82}$

The Lama and Tulku Dosher Thubten Lamsang (Bla sprul Rdo gzher Thub bstan lam bzang) of Phagri, when visiting Darjeeling (Rdor gling) in India, observed a few foreigners (British?) and Germans (dbyin ji dang 'ja' man) experimenting with mercury. He inquired what they were doing, and they replied that they were transforming mercury into medicines. The lama himself thought of mercury as being highly poisonous (dug chen po yod) and not as a medicine [so, he probably did not know about the medical use of mercury in Tibetan traditions]. Soon after, he again observed some foreigners (dbyin ji) in Western Tibet (Stod) experimenting with mercury in hot spring water for medicinal purposes. A few months later, he was back in Phagri to renovate the Drathok (Bra thog) Monastery and build a retreat place called Richung Potho (Ri chung spo mtho). During the restoration

76 Dawa Ridak (2003: 411) and Sonam Bakdrö (2006: 47) place this event in the earth-mouse year 1948; Tenzin Chödrak (1994: 117) in 1951; Tenzin Chödrak/van Grasdorff (1999: 123) in the iron-tiger year 1950. I am following Sonam Rinchen and think 1953 is accurate, since it tallies with Chödrak's graduation and it is unlikely, though not impossible, that he would have been sent away for several months before his graduation.

77 Phagri (in Pinyin Pàlǐ zhèn) is located in Yadong County in the Tibet Autonomous Region (TAR).

78 Dhondup Wangyal Khangkyil 2008: 34. Thanks to Tashi Tsering for this information and the reference.

79 Tashi Tsering, personal communication, Dharamsala, India, July 2014.

80 Sonam Rinchen 2000: 59-60.

81 Sonam Rinchen 2000: 61.

82 Summarised from Sonam Rinchen 2000: 60-62. Chödrak/van Grasdorff 1999: 123-124 mentions that the 'Tulku Dosha' met a German scientist experimenting with mercury in Darjeeling, which inspired him to search for a Tibetan mercury text after returning to Phagri. 
work he found a Tibetan text on mercury processing. ${ }^{83}$ Remembering the foreigners experimenting with mercury, he realised that there is a Tibetan tradition of processing mercury. Consequently, he sent a letter to Khyenrab Norbu in Lhasa requesting him to come to Phagri to make tsotel. Thubten Lamsang offered to sponsor the precious ingredients required for the practice. This is how Tenzin Chödrak came to Phagri to make tsotel.

Tenzin Chödrak had heard of the explosions of clay pots in 1921 and the dangers surrounding it. He therefore took the old stone pot from Chakpori that had been used by the "previous regent". ${ }^{84}$ This pot, in which mercury had boiled almost three hundred years earlier-presumably during the tsotel event below the Potala in $1669^{85}$-was carried to Phagri. There, most of the smaller clay pots either burnt or broke while burning the gold. This problem was solved when Tenzin Chödrak added an additional layer of soil/clay $(s a)$ inside the pots.

It is not mentioned who else apart from Tenzin Chödrak, Palden Gyaltsen, and Tulku Thubten Lamsang was present in Phagri. For some reason, Tenzin Chödrak does not acknowledge the important role Palden Gyaltsen played in his own tsotel transmission. He clearly admits that he himself had never received the "seeing transmission" for making tsotel. ${ }^{86}$ It is very likely that he received this transmission from Palden Gyaltsen. Unfortunately, none of the contemporary physicians I asked in Dharamsala knew anything about Palden Gyaltsen's tsotel lineage, and there is no published biography of his life. But Gen Rinpoche Lozang Tenzin Rakdo in Sarnath recalled clearly that while he worked at the Men-Tsee-Khang in Dharamsala (1988-1993), Tenzin Chödrak told him personally that Palden Gyaltsen received the tsotel lineage of Darma Senge (Dharma Seng ge, died 1889?) from Eastern Tibet, ${ }^{87}$ maybe through one of his students, and thus most likely passed on the "seeing transmission" to Tenzin Chödrak in Phagri. $^{88}$

It is not clear why Tenzin Chödrak did not acknowledge Palden Gyaltsen's role, and thus the "seeing transmission" lineage of Darma Senge in his biography. There might be more to the story, since Jampa Trinlé's biography of Darma Senge also does not mention him making tsotel, but depicts him as a specialist

83 Unfortunately, the title is not mentioned.

84 This refers to Desi Sangye Gyatso (Sde srid Sangs rgyas rgya mtsho, 1653-1705). Interview, Sonam Rinchen, Sherabling, India, 2.7.2014.

85 Dawa Ridak 2003: 409.

86 Sonam Rinchen 2000: 62.

87 Darma Senge is also known as Karma Jigme Chökyi Senge (Karma 'jigs med chos kyi senge) or Zhenpen Oeser (Gzhan phan 'od zer). See Jampa Trinlé 2000: 418-422 for his biography without dates. Tashi Tsering notes that Darma Senge died in 1889 (2015: 698).

88 Gen Rinpoche Lozang Tenzin Rakdo (hereafter Rakdo Rinpoche), Interview, Sarnath, India, 16.3.2015. 
in consecration (sman grub) and medicine ritual practices, especially the Yuthok Nyingthig cycle (G.yu thog snying thig). ${ }^{89}$ It is documented that he gave this transmission to the entire medical community at Chakpori. ${ }^{90}$ We know that Darma Senge was trained at Kathok (Ka thog) Monastery in Eastern Tibet, which had a tradition of making tsotel; he could have been trained by Kongtrül Yönten Gyatso (Kong sprul yon tan rgya mtsho, 1813-1900). ${ }^{91}$ Orgyen Tenzin, who made tsotel in Lhasa in 1893, invited Darma Senge at some point to come to Lhasa. ${ }^{92}$ Darma Senge had several personal students, one of whom could have trained Palden Gyaltsen before 1953.

It appears that in his biography, Tenzin Chödrak wanted to emphasise the textual transmissions he received from his teacher Khyenrab Norbu in Lhasa more than his "seeing transmission". His adherence to a certain regionalism of medical knowledge transmission might have played a role here (see conclusion). The biography prominently enumerates the transmissions he received from Khyenrab Norbu: i.e. the lung and oral transmission of Kongtrül Yönten Gyatso's text on tsotel, ${ }^{93}$ along with oral instructions; the textbook (yig cha) of Situ Chökyi Jungne (Si tu Chos kyi 'byung gnas, 1699/1700-1774), ${ }^{94}$ as well as the oral transmission (khrid lung) and oral instructions according to the Mindroling Drepung (Smin grol gling 'Bras spungs) lineage. ${ }^{95}$

The fifteen kilograms of tsotel made at Phagri largely went to the sponsor Tulku Thubten Lamsang. ${ }^{96}$ Tenzin Chödrak presented two kilograms of tsotel to his teacher Khyenrab Norbu, back in Lhasa, but it is not mentioned what type of precious pills they made, when, and where. After this event, Khyenrab Norbu wanted Tenzin Chödrak to teach mercury processing at the Mentsikhang in

89 Jampa Trinlé 2000: 418-422.

90 Thubten Tsering 1986: 174, in Gerl/Aschoff 2005: 48, 73.

91 Rakdo Rinpoche, Interview, Sarnath, India, 16.3.2015.

92 Kilty 2010: 21.

93 The text was probably used in Lhasa and is titled Bdud rtsi bcud kyi rgyal po dngul chu btso bkru chen mo'i sbyor bas grub pa'i bcud len tu bsgyur ba'i lag len mam par gsal ba 'tsho byed mkhas pa’i snying bcud. Tashi Tsering 1986: 393-441. Chödrak refers to this text as the easiest to follow. Sonam Rinchen 2000: 103.

94 This text, written by Gurupel (Gu ru 'phel), is based on the oral instructions of Chökyi Jungne, titled Srid gsum gtsug rgyan si tu chos kyi 'byung gnas kyi zhal lung dngul chu btso chen dang rin chen ril bu'i sbyor sde zla ba bdud rtsi'i thig le ces bya ba bidza ha raM. Tashi Tsering 1986: 303-391. Situ Chökyi Jungne himself authored Dngul chu btso bkru chen mo'i lag len 'chi med bdud rtsi'i bsrubs shing, an extant but unpublished manuscript on mercury processing. Czaja 2013: 90.

95 Sonam Rinchen 2009: 47. Sonam Rinchen told me that this Mindroling lineage is orally transmitted. Interview, Sherabling, India, 2.7.2014.

96 Interview with Sonam Rinchen, Sherabling, India, 2.7.2014. 
Lhasa, but with the post-1951 annexation of Central Tibet by the Chinese Communist Party the opportunity did not arise, and in 1959 Tenzin Chödrak was imprisoned. ${ }^{97}$ However, Jampa Trinle writes in his autobiography that in 1963 the precious pill Ratna Samphel was manufactured at the Lhasa Mentsikhang, but he does not mention where the tsotel came from. ${ }^{98}$ Contemporary Tibetan authors mention the Phagri event as evidence that the tsotel lineage of the Mentsikhang continued uninterruptedly. ${ }^{99}$

Before commencing the next section, a short summary of Troru Tsenam's life and tsotel training is required. Troru Tsenam was born in $1926^{100}$ in Derge, Kham (now Kardzé (Dkar mdzes) Autonomous Prefecture, Sichuan Province), and studied Buddhism and medicine at Kathok Monastery near Derge, where he received oral transmissions on mercury processing from Tachung Lama Tsering Chöpel (Rta chung Bla ma Tshe ring chos 'phel). He stayed at Kathok monastery until $1956,{ }^{101}$ where he experimented with mercury, but did not succeed in making tsotel himself. ${ }^{102}$ His namthar has a dedicated chapter titled "Processing mercury for the first time" (dngul chu btso bkru thengs dang po mdzad tshul), which tells the story of how Troru Tsenam made his first tsotel at Powo Tramo in 1977. Before that, however, Troru Tsenam was imprisoned for ten years (1960-1970) at Powo Tramo, where he established a small prison clinic in 1971 after his partial release, his skills as a doctor having been formally recognised. ${ }^{103}$ He remained under surveillance, which included travel restrictions, even in the 1980s, when he was teaching medicine in Lhasa. ${ }^{104}$

\section{Making tsotel at Powo Tramo in 1977}

How could Tibetan doctors make tsotel in a labour camp in 1977 after years of persecution and the death of many of their fellow physicians? To answer this question we need to consider that the attitudes of the newly established PRC

97 Sonam Rinchen 2009: 47.

98 Jampa Trinlé 2006: 32-33. Amchi Lobsang Tsultrim (1921-2004?) recalled that Ratna Samphel was made at the Mentsikhang with tsotel from Kham (Stephens and Tsarong 1992: 13). 99 Sonam Bakdrö 2006: 47.

1001926 is the correct corresponding year for the fire-tiger year of the fifteenth Tibetan Rabjung. Lozang Lodrö 2006: 7-8. Holmes 1995: 144 mentions 1928.

101 Holmes 1995: 144.

102 Lozang Lodrö 2006: 235.

103 Lozang Lodrö 2006: 168, 172.

104 Rakdo Rinpoche, interview, Sarnath, 16.3.2015. 
governing bodies towards Tibetan medicine changed several times after the Chinese invasion of Tibet: In Central Tibet, from 1951 to 1962, Tibetan medicine was largely ignored; from 1962 to 1966 it was integrated into the official public health system, even receiving government funds; throughout the Cultural Revolution (1966-1976) it was delegitimized and attacked by the Red Guards as one of the "four olds", and the Mentsikhang's activities were interrupted. Things began to relax a little in 1974 when Tibetan medicine was officially taught again in Lhasa. ${ }^{105}$ The mercury processing event described in this section is historically situated at a time when Tibetan medicine was in its most devastated state during the twentieth century, but also at a turning point because of newly emerging strategies to use it in "culturally compatible" ways to serve rural populations. $^{106}$

Under what conditions did the Tibetan doctors process mercury in the labour camp? How were they able to keep up the complex knowledge transfer of oral, textual, and practical transmissions? The two biographies tell the story with different emphases on how the two physicians were personally involved in the supervision of the manufacturing process. It is thus difficult to reconstruct the event and get any insight into the relationship between the two physicians. As stated above, they hardly mention each other, apart from acknowledging the other's presence at the event through mentioning their names. Each physician is depicted as being at the centre of the event and instrumental in its organisation and supervision. Nevertheless, both biographies provide descriptions that can be compared and allow for a certain reconstruction of the contexts, circumstances, methods, and challenges involved in the process. The dire situation of the tsotel practice being at the verge of extinction undoubtedly comes through in both narratives. The event is summarised below, comparing both sources.

In Troru Tsenam's biography, the story begins in the sixteenth Tibetan Rabjung, in the wood rabbit year $(1975)^{107}$ with an encounter with a Chinese official, who had arrived from Lhasa to question Troru Tsenam on the most important aspects of Tibetan medicine. This perhaps adds evidence to our current knowledge of Chinese authorities beginning to take renewed interest in Tibetan medicine. Troru Tsenam responded to this inquiry by pointing to the making of tsotel and precious pills as the most essential aspect of Tibetan

105 Hofer in preparation.

106 Janes 1995: 20. See also Hofer 2011: 154-156 on the changing status of Tibetan medicine in Ngamring in the early 1970s, and Hofer in preparation.

107 Lozang Lodrö 2006: 173 equates this with the year 1977, which, however, was a fire-snake year. 
medicine. ${ }^{108}$ The conversation then hinged on issues of authority. Lozang Lodrö describes the conversation between Troru Tsenam and the Chinese official as follows:

Following that, the official asked, 'Can you make this so-called tsotel?' Khen Rinpoche replied in a matter-of-fact and confident manner, 'If I have the materials and authority (dbang cha) then it's certain that I can make it.' At that moment the official shrank back and said, 'Well, well, he thinks he needs authority.' Realising that the official had misunderstood the meaning of what he had said, Khen Rinpoche said, 'When I say, I need authority, I don't mean political authority at all. I meant the authority to organise the preparation of medicine. If I don't have the authority to direct the entire manufacturing practice as it should be done, there will be great difficulty in preparing the medicines, and there is even the possibility that I would not be able to complete the preparation process.' The official then understood the situation, and said, 'OK, from now onwards you can begin arranging the materials to prepare the medicines.'109

At around the same time Tenzin Chödrak was breaking stones in a labour camp, and after treating some Chinese leaders successfully, he was asked to set up a small prison clinic. From there he was ordered to Powo Tramo to join the making of tsotel during the fire-dragon year of $1976 .{ }^{110}$ Powo Tramo is one of the main detention facilities east of Lhasa in the town of Tramo in Powo, Kham, today administered under Nyingtri (Nying khri) prefecture, Kongpo (Kong po).

According to Sonam Rinchen, ${ }^{111}$ the reason for making tsotel at Powo Tramo goes back to a Tibetan regiment commander ( $r u$ dpon) named Tsegyal (Tshe rgyal), who was sympathetic towards the prisoners. In 1974, he was appointed health director at Powo Tramo, where he built a small prison clinic together with other physicians, namely Tsultrim (Tshul khrims), ${ }^{112}$ Thubten Sakya (Thub stan Shakya), ${ }^{113}$ and Derge Tsenam (Sde dge Tshe rnam, i.e. Troru Tsenam). ${ }^{114}$ Among them, Tsultrim was the senior amchi and Troru Tsenam and Thubten Sakya were appointed as assistants to run the clinic. They financed this clinic by making medicinal syrups, which they traded with the Mentsikhang in Lhasa for other medicines. Together, these doctors felt the need to make precious pills, for which they had to process mercury. According to Sonam Rinchen, they decided

108 His quote is published in Gerke 2013: 111.

109 Translated from Lozang Lodrö 2006: 173.

110 Sonam Rinchen 2000: 101.

111 Sonam Rinchen 2000: 101-104.

112 Amchi Tsultrim was appointed part-time doctor at the clinic after curing a very high military officer. Sonam Rinchen 2000: 102.

113 Thubten Sakya was known for his experience in burning precious metals, but had never made tsotel. Sonam Rinchen 2000: 105.

114 Sonam Rinchen 2000: 102. 
to search for old pharmacology texts and experienced senior doctors who had survived the Cultural Revolution and remembered how to make tsotel. They unanimously decided that Troru Tsenam would go to Derge and Yeshe Dorjé (Ye shes rdo rje), one of the other physicians present, to Lhasa to fulfil this mission. ${ }^{115}$ According to the two biographies, Troru Tsenam found a text in Derge, and Yeshe Dorjé found an imprisoned physician with practical tsotel experience near Lhasa-Tenzin Chödrak.

The identity of the text that Toru Tsenam brought from Derge is unclear. Jamyang Lhundrup from Lokha recalled that Troru Tsenam "had a small, old, ragged volume that was barely legible due to stains and filth that he said he had brought from Derge. Based on that they were able to prepare authentic tsotel. ${ }^{116}$ Sonam Bakdrö mentions that Troru Tsenam relied mostly on the notes written by Kongtrül Yönten Gyatso, which he obtained from the physician Püntsog Tashi (Phun tshogs bkra shis). ${ }^{117}$ Holmes mentions this was "Thai Situpa's text on mercury", ${ }^{118}$ which refers to the text by Situ Chökyi Jungné's student Gurupel mentioned above. The same text is mentioned in Thubten Phuntsok's short namthar of Troru Tsenam. ${ }^{119}$

Finding Tenzin Chödrak was also not easy. Sonam Rinchen tells the story of how in Lhasa, Yeshe Dorjé went to the homes of well-known doctors of the past, like the Nyarongshag family, to look for physicians trained in making tsotel, but he was unsuccessful. ${ }^{120}$ At the Mentsikhang, he met an old nun, called Ani Ngawang, ${ }^{121}$ who had made tsotel with her own Lama, Nyime Dorjé (Gnyis med rdor rje), ${ }^{122}$ who had since died. The nun was "too old to make tsotel again", but she recalled that a physician named Tenzin Chödrak, who was currently in prison, had made tsotel previously. Through Tsegyal's advocacy, Yeshe Dorjé received permission to discuss the necessary ingredients and methods with Tenzin Chödrak at the prison. There, Tenzin Chödrak instructed him to find the text by Kongtrül Yönten Gyatso, for which he had received the

115 Sonam Rinchen 2000: 102.

116 Lozang Lodrö 2006: 176.

117 Sonam Bakdrö 2006: 47, 56, quoted in Czaja 2013.

118 Holmes 1995: 145. See footnote 95.

119 Thubten Phuntsok 1994: 33.

120 Sonam Rinchen 2000: 103-104.

121 This might be the same Ani Ngawang from Nyemo mentioned by Fjeld/Hofer 2010-2011: 180, 186. Theresia Hofer, personal communication, July 2014. However, Fjeld/Hofer give her dates as c. 1930-2006, which makes me wonder why Yeshe Dorjé found her "too old to make tsotel again" when she must have only been in her forties.

122 Hofer thinks this is Kyemen Rinpoche (Skye med Rin po che) from Kham, the lama of Ani Ngawang in Ngamring. Personal communication, July 2014. 
transmissions. He also described to him in detail the old stone caldron from Chakpori which he had used in Phagri in 1953 and gave him clear instructions about what a suitable pot should look like. Eventually, Tsegyal secured permission for Tenzin Chödrak to join the others in Powo to process mercury. Tsegyal's words to Tenzin Chödrak are reported as follows:

"Right now our Sorig doctrine [= Tibetan medicine] has arrived at a very poor state; not only that, in particular the tsotel practice has become very rare in the Tibetan region from what we have researched. It is very difficult to obtain and is largely practised in secret, etc. Regarding this practice, at the moment you are the only one left, so please help and make your best effort," he requested. ${ }^{123}$

This statement by Tenzin Chödrak to Sonam Rinchen shows the delicate condition that the Tibetans at Powo perceived the knowledge of mercury processing to be in at the time. In comparison, Troru Tsenam's namthar states that "Khen Rinpoche realised that the excellent tradition of making tsotel had been degenerating for more than fifty years". ${ }^{124}$ Here, the biographer skips the 1953 event at Phagri, which he probably did not know about. Lozang Lodrö depicts Troru Tsenam as the saviour of the tsotel practice and the main figure "to pass on the texts, secret instructions, and practical transmissions without any mistake". ${ }^{125}$ Through his way of writing, Lozang Lodrö officially establishes Troru Tsenam as the main lineage holder of the tsotel practice for training future doctors in the PRC, a position Troru Tsenam actively fulfilled during his lifetime.

To date I found only one source that mentions that a few years earlier, in 1973 and 1974 the great medicine provider Thabkey Phuntsok (Sman gnyer chen mo Thabs mkhas phun tshogs) from the Mentsikhang in Lhasa apparently made tsotel in two stages. ${ }^{126}$ In 1973, despite this still being a difficult period for Tibetan medicine, he accomplished the burning of the "eight metals" and "eight elements" in Kongpo, ${ }^{127}$ and in 1974 he completed making tsotel at Yuthok Shar (G.yu thog shar) in Lhasa. ${ }^{128}$ Thabkey Phuntsok apparently trained Tenzin Namgyal (Bstan 'dzin rnam rgyal), ${ }^{129}$ who escaped to India in 1981 and

123 Sonam Rinchen 2000: 104.

124 Lozang Lodrö 2006: 237.

125 Lozang Lodrö 2006: 237.

126 Dawa Ridak 2003: 411.

127 Namgyal Tsering, former head of the Men-Tsee-Khang pharmacy in Dharamsala, suggested that it was less difficult to burn the metals into ash in Kongpo, where wood was more easily available than in Lhasa. Personal communication, New York, October 2014.

128 Dawa Ridak 2003: 411.

129 Dawa Ridak personal e-mail communication 31.5.2014, in which he states that Tenzin Namgyal told him this personally. Other Men-Tsee-Khang physicians described Tenzin 
was appointed Head of the Pharmacy at the Dharamsala Men-Tsee-Khang until his death in $1991 .^{130}$ Tenzin Namgyal made tsotel at the Men-Tsee-Khang in Dharamsala in India with Tenzin Chödrak and others in 1982 and 1987, ${ }^{131}$ but no publications acknowledge his earlier tsotel training.

How can we interpret the fact that Yeshe Dorjé, while looking for doctors knowledgeable about tsotel at the Mentsikhang, did not come across the information that Thabkey Phuntsok had just made tsotel a couple of years before? We should keep in mind here that even though the Mentsikhang remained open throughout the Cultural Revolution, "by 1973 Tibetan medicine as an institution had virtually disappeared". ${ }^{132}$ One could assume that Thabkey Phuntsok's pharmacological efforts were not common knowledge at the Mentsikhang. Sonam Rinchen's impression is that the situation for Tibetan doctors was so dire towards the end of the Cultural Revolution that probably not many people knew about Thabkey Phuntsok's gradual mercury processing. ${ }^{133}$ Moreover, since the barefoot doctor campaign at the time aimed at simplifying medical treatments, ${ }^{134}$ a complicated pharmacological procedure would not have been advertised.

According to Lozang Lodrö, the actual tsotel event took place in the Tibetan fire-snake year $1977^{135}$ in the upper valley of Drushitang (Gru shis thang), which is not too far from Powo Dochuthil (Spo bo Mdo chu mthil). Lozang Lodrö lists the physicians present as:

the court physician Tenzin Chödrak, Thupten Shakya from Mentsikhang (Sman rtsi khang gi Thub bstan sha'kya), Rigzin Wangyal from Khyungpo (Khyung po ba Rig 'dzin dbang rgyal), Yeshi Dorjé from Tolung (Stod lung ba Ye shes rdo rje), Jamyang Lhundup from Lhokha (Lho kha 'Jam dbyangs lhun grub, b. 1938), ${ }^{136}$ and also the teacher Tsegyal (Rgan Tshe rgyal) and the physician Tamkha Ngawang Gyatso (Tham kha Ngag dbang rgya mtsho, 1930-2004), who came especially from Derge to participate and offer assistance. ${ }^{137}$

Namgyal to me as very experienced during tsotel preparations, but his previous training and tsotel transmissions were not talked about, perhaps out of respect for Tenzin Chödrak as the Dalai Lama's personal physician.

130 Kloos 2010: 80, 88.

131 Dawa Ridak 2003: 411.

132 Janes 1995: 20.

133 Interview with Sonam Rinchen, Sherabling, India, 2.7.2014.

134 See Hofer, in preparation, on the barefoot doctor movement among Tibetan physicians.

135 Lozang Lodrö wrongly correlates this to 1979 (2006: 175, 241), which was an earth-sheep year. I tend to go with the Tibetan year, which Tibetans will more clearly remember than the 'Western year' (phyi lo). Thubten Phuntsok (1994: 33) mentions 1977 and Sonam Bakdrö (2006: 57) 1979.

136 For his biography, see Jampa Trinlé 2000: 613-617. He taught the tsotel practice in 1996 at Lhasa Mentsikhang college. Jampa Trinlé 2000: 616-617.

137 Lozang Lodrö 2006: 175-176, cf. 241. On Tamkha Ngawang Gyatso's life and his tsotel manufacturing see Yeshe Gonpo 2005. Thanks to Tashi Tsering for sharing this reference. 
Some of these doctors survived these harsh years and later passed on the tsotel lineage to other students. For example, Jamyang Lhundup made around ten to fifteen kilograms of tsotel at the Mentsikhang in Lokha in 1991 together with Karma Chöphel, after having taken part in the making of tsotel several times in other Mentsikhang pharmacies in Lhasa and Chamdo in the 1980s. ${ }^{138}$ Karma Chöphel was apparently also trained by Troru Tsenam in Powo Tramo, ${ }^{139}$ but he is not mentioned in Lozang Lodrö's list above.

It apparently took about two years to arrange for the equipment, ingredients, and various pots needed to burn the eight metals into ash and to boil the mercury. Both Lozang Lodrö and Sonam Rinchen mention that the most difficult challenge was to organise a suitable pot to boil mercury. Lozang Lodrö writes that the physician Jamyang Lhundrup, who at the time was undergoing labour reforms in Chudo (Chu mdo), went from house to house trying to borrow a suitable pot. In the end, they found a stone pot that was used to boil alcohol. ${ }^{140}$ Tenzin Chödrak tells the story of how mercury was boiled with sulphur and salt inside this pot. Recalling the danger of explosion, they placed forty kilos of rocks on top of the pot, but these kept falling off and the doctors were worried. Eventually, Tenzin Chödrak himself climbed on top to keep the lid down with his own body weight, which was considered very courageous. ${ }^{141}$ This story is not brought up by Lozang Lodrö, perhaps in part because official PRC biographies could not easily talk about accomplishments of Tibetan exile physicians.

Another challenge was to arrange pure gold, which is portrayed varyingly in the biographies. Gold is one of the eight metals burnt to ash when making tsotel. Being able to burn gold into ash is something Tibetan physicians pride themselves with. It was not easy for the Tibetans to convince the Chinese to provide pure gold for this event, since apparently any action that could be interpreted as arrogance or disobedience could lead again to imprisonment or re-education sessions. Lozang Lodrö writes that the Chinese official responded to Troru Tsenam's request for gold unwillingly: "There is a saying in China: 'Pure gold is not scared of fire.' There is a great danger that you might be put in prison again". ${ }^{142}$ Troru Tsenam eventually convinced the official to give him the gold by explaining the technical process of burning gold to ash. Tenzin Chödrak's

138 Interview with Yeshe Gelek, Dharamsala, India, 30.10.2012.

139 Interview with Yeshe Gelek, Dharamsala, India, 30.10.2012. Interview with Sonam Rinchen, Sherabling, India, 2.7.2014.

140 Lozang Lodrö 2006: 174.

141 Sonam Rinchen 2000: 106.

142 Lozang Lodrö 2006: 174. 
biography recalls that they received Chinese gold engraved with numbers, but they doubted its purity. They eventually found pure Tibetan gold bangles underneath a motor repair centre, which they were somehow allowed to use. ${ }^{143}$ The German "auto-biography" 144 mentions that they were first given melted gold of inferior quality and then on Chödrak's request pure gold directly from the mines.

Overall, according to Sonam Rinchen, it took them one month to make tsotel. Lozang Lodrö mentions forty-five days. ${ }^{145}$ At Powo Tramo they made thirty-eight gyama (rgya ma) of tsotel (approximately nineteen kilograms). ${ }^{146}$ It is not clear where and how they made precious pills, but Sonam Bakdrö writes that Rinchen Drangjor, Rinchen Mangjor, Ratna Samphel, Yunying 25, Jumar 25, Rinchen Wangril 25, and others, were made with the tsotel of $1977 .{ }^{147}$

In the 1980s, the situation for Tibetan medicine changed considerably and tsotel was made at least six times between 1980 and 1989 at various pharmacies in Tibet. ${ }^{148}$ According to Lozang Lodrö, Troru Tsenam thoroughly trained thirty physicians in tsotel manufacturing. ${ }^{149}$ Tenzin Chödrak arrived in India in 1980 and was instrumental in the revival of the tsotel practice at the Men-Tsee-Khang in Dharamsala. The details of these events still require further research.

\section{Conclusion}

Throughout its history, the knowledge of Tibetan mercury processing techniques, especially the difficult preparation of the mercury-sulphide ash called tsotel used in precious pills faced challenges. Since its manufacturing was expensive and the expertise often limited to a few individuals, the transmission of this medical knowledge could easily be curtailed by political upheavals, with the danger of the lineage being interrupted. ${ }^{150}$ However, the continuation of a certain lineage also depended on how it was documented and presented in an authoritative way, such as through official biographies of physicians.

143 Sonam Rinchen 2000: 105.

144 Chödrak/van Grasdorff 1999: 263.

145 Sonam Rinchen 2000: 106, Lozang Lodrö 2006: 241.

146 Lozang Lodrö 2006: 241.

147 Sonam Bakdrö 2006: 48.

148 Sonam Bakdrö 2006: 57. This number is probably higher considering undocumented tsotel events.

149 Lozang Lodrö 2006: 247. The actual number of physicians trained is probably also higher. 150 Czaja 2013. 
This paper discussed how the twentieth century brought the knowledge transmission of the tsotel practice to a critical point. While the years from 1916 to 1924 can be seen as 'golden' for the development of Tibetan medicine in Central Tibetan government institutions, when tsotel was made twice within three years, the decades from the late 1950s until the late 1970s almost led to the extinction of the practice in institutionalised settings. ${ }^{151}$

The Cultural Revolution and the period before and after were among the most challenging years for Tibetan doctors to pass on the knowledge of making tsotel. Even though there might be other regions in Tibet where the tsotel practice survived, in the 1970s it hinged on the lives of a few individuals living in extremely difficult circumstances and making substantial sacrifices to uphold their medical traditions. Tibetan medical practice today would probably look quite different if the two physicians presented here, Troru Tsenam and Tenzin Chödrak, had not survived their imprisonment and died like so many other inmates. Tenzin Chödrak was able to make tsotel twice, in 1953 and in 1977, before teaching the practice in India. Considering the tremendous revival of tsotel and precious pill production since the 1980s and the role tsotel manufacturing plays in today's Tibetan medical industry, the tsotel event of 1977 is historically significant in that it not only led to the tsotel knowledge transmission to several physicians from various regions, but also provided the narratives for retrospectively establishing two authoritative lineage holders, one in the PRC and one in India.

From the perspectives of the two modern biographies presented here, each of the physicians appears to have had the leading role in the 1977 tsotel event. This was probably influenced by several things, such as the ways individual memory works, as well as the ways Tibetan biographies are written, adopting the namthar genre's style of highlighting the master and his accomplishments. I think the necessity to retrospectively construct an authoritative continuum of knowledge transmission for future generations of Tibetan physicians in the PRC and India was equally if not more decisive in the writing of these biographies. Tenzin Chödrak was apparently the more experienced physician in 1977 and passed on the "seeing transmission" to Troru Tsenam. ${ }^{152}$ However, Lozang Lodrö could not have presented Tenzin Chödrak, who was after all the court physician of the Dalai Lama, in a prominent teaching position, when establishing a line of transmission and authority for Tibetan doctors in the PRC. I could not yet

151 Tsotel practices might have survived on smaller scales in Kham or elsewhere.

152 Rakdo Rinpoche also remembers Troru Tsenam telling him in Lhasa that Tenzin Chödrak was the main person guiding the tsotel event in 1977. Interview, Sarnath, 16.3.2015. 
examine this aspect in other biographies of Troru Tsenam, ${ }^{153}$ therefore my conclusions are preliminary.

We also still do not know for certain why Khyenrab Norbu, in charge of the Mentsikhang from 1916 to 1962, did not make tsotel in Lhasa in the 1930s and 1940s, when circumstances would have still been favourable. While various publications prominently mention that he received the tsotel transmission in 1919 and 1921, according to two sources he was not really experienced in the tsotel practice and therefore sent Tenzin Chödrak to Phagri in 1953 to learn it. ${ }^{154}$ These discrepancies require further research and tell us that biographies reveal "practices of historical narration" to use Trouillot's term. ${ }^{155}$ It is good to remember that "any historical narrative is a particular bundle of silences, the result of a unique process, and the operation required to deconstruct these silences will vary accordingly". ${ }^{156}$ It is not easy to deconstruct the silences and discrepancies in the two biographies and to draw firm conclusions about who taught whom at Powo Tramo as well as who gave the "seeing transmission" to Tenzin Chödrak. We know too little about the ways in which PRC censorship, Dharamsala politics, and the individual authors' agency dictated what was left out and put into the biographies. I tried to fill some of the gaps by discussing the two biographies with several contemporary Tibetan physicians and scholars. From these discussions I conclude that the way events are told or kept silent might have been affected by a certain kind of Tibetan regionalism. ${ }^{157}$ For example, the affiliation of Tenzin Chödrak to Khyenrab Norbu, the Dalai Lama, and the Tibetan government institutions in Lhasa and Dharamsala on the one hand, and Palden Gyaltsen's passing on the "seeing transmission" from the Eastern Tibetan lineage of Darma Senge on the other, might have influenced the ways in which medical history is perceived and officially told along the lines of regional favouritism.

In India, a detailed biography of the Dalai Lama's personal physician served to establish an authoritative lineage of tsotel transmission at the

153 I received four other namthars of Troru Tsenam (published in various Tibetan journals) at the end of this project from Tashi Tsering, but could not study them for this paper.

154 Rakdo Rinpoche remembers Tenzin Chödrak privately mentioning this as a reason for his training in Phagri. Interview, Sarnath, 16.3.2015. Amchi Lobsang Tsultrim mentions that the tsotel practice declined at the Mentsikhang because Kyenrab Norbu had no experience in making it and that the main teacher in the 1950s was Nyarongshag (Stephens and Tsarong 1992: 12).

155 Trouillot 1995.

156 Trouillot 1995: 27.

157 I thank Tashi Tsering in Dharamsala and Rakdo Rinpoche in Sarnath for discussing these aspects with me. 
Men-Tsee-Khang in Dharamsala, where they were able to make tsotel successfully only after Tenzin Chödrak arrived. The importance of linking Tenzin Chödrak's lineage back to Khyenrab Norbu and thus the Mentsikhang in Lhasa should not be underestimated here, since the Men-Tsee-Khang in Dharamsala sees itself as a direct continuation of the Lhasa Mentsikhang. ${ }^{158}$ Both biographies therefore fulfil an important role in the context of Tibetan medical knowledge transmission: to provide the official and authoritative account of the main lineage holder. Thus, they successfully achieve what namthars are meant to do in Tibetan societies. If "authenticity is not a type or degree of knowledge, but a relationship to what is known", ${ }^{159}$ it is not for us to question the authenticity of the knowledge contained in these biographies (since they serve a particular purpose) but to unravel the authors' relationships to that knowledge.

Aspects that I find equally interesting in the two biographies and which raise new research questions, are smaller facts mentioned the peripheries of the main narratives. Apparently, making tsotel was not the sole prerogative of large institutions with government support. Some individuals seem to have procured the knowledge and funds to make it. Unfortunately, the information on smaller tsotel events outside the medical institutions is still sparse. The importance of ethnographically collecting oral histories from senior physicians is thus an important tool for arriving at a more complete picture on smaller-scale tsotel practices and related networks. ${ }^{160}$ For example, I interviewed a senior Tibetan physician, Amchi Wangchuk, in Kathmandu in 2011, who made tsotel twice in a small monastery in Kyirong in South Central Tibet in 1955 and 1958, but was unable to make it again in exile. ${ }^{161}$ Moreover, if we take seriously the encounter of Yeshe Dorjé with Ani Ngawang in Lhasa, women were making tsotel, which is traditionally prohibited. Hofer reports that students of Ani Ngawang and her teacher, Kyemen Rinpoche, continued making tsotel at the Tekchen Chöling Gonpa in Nyemo. ${ }^{162}$ Rakdo Rinpoche, who lived three years with Troru Tsenam in Lhasa in the 1980s before coming to India in 1987, also made two kilograms of tsotel with him and a small group of doctors from Kham, including Kunup Özer (Sku nub 'od zer) and the woman physician Jetsunma Do

158 One case here is the current preparations underway for the 100-year Lhasa Mentsikhang celebrations at the Men-Tsee-Khang in Dharamsala in 2016.

159 Trouillot 1995: 149, quoting Cascardi 1984: 289.

160 See, for example, the published interview with Amchi Lobsang Tsultrim on Nyarongshag making tsotel with Trogawa Rinpoche in Lhasa in 1954 and the Mentsikhang receiving tsotel from Kham (Stephens and Tsarong 1992).

161 Gerke 2013.

162 Hofer, in preparation. 
Dasel Wangmo (Rje btsun ma Mdo Zla gsal dbang mo). She was permitted to partake in most of the manufacturing, except on certain days. ${ }^{163}$ These smaller events are hardly ever written about, but an ethnographic documentation of the oral histories surrounding them points to the heterogeneous and interrelated practices of Tibetan medicine and deserves further research. A combination of a critical reading of biographies and collecting oral histories from senior physicians would probably unearth further medical knowledge transmissions of tsotel practices. To date, we know too little about family or monastic traditions of making tsotel privately or in rural Tibetan areas to draw conclusions on the overall status of Tibetan mercury processing.

Another intriguing observation is the apparent freedom with which Tibetan doctors travelled across Tibet just after the Cultural Revolution while being classified inmates at a labour camp. It is difficult to imagine how Toru Tsenam could travel to Derge to look for texts. Before reading too much into these travel narratives, further research is required. Rakdo Rinpoche, who talked extensively to Troru Tsenam during their years together in Lhasa, said that Troru Tsenam never mentioned a journey to Derge; considering his ongoing surveillance into the 1980s, where he had to report to the local authorities every month and was not free to travel, Rakdo Rinpoche thought it unlikely that it could have taken place. Troru Tsenam's namthar also mentions that in 1979, when most prisoners of Powo Tramo were released, he was not permitted to go to Derge despite his repeated requests, but had to work as a physician in Lhasa instead. ${ }^{164}$ Other Tibetans I spoke with thought that he might have been able to travel to Derge with a special permit.

Tsotel practices continue to exist in the twenty-first century both in the PRC and in India, drawing their authority largely from the two main celebrated lineage holders introduced here. ${ }^{165}$ This has not only influenced the commodification of Tibetan precious pills, ${ }^{166}$ but has been central to the growing Tibetan medical industry, a development that would have been difficult to imagine when mercury was boiling in an old stone pot at a labour camp in Powo in 1977.

Acknowledgements: I am grateful to the German Research Foundation (DFG project No. 53307213 and No. 55127201) for funding the research and the writing of this article. Thanks to Dr Dawa Ridak, Dr Choelothar, Dr Yeshe Gelek,

163 Interview with Rakdo Rinpoche, Sarnath, 17.3.2015.

164 Lozang Lodrö 2006: 176-177.

165 During a Tibetan medicine workshop in Kathmandu, in 2011, all participants from across the PRC said they had received their tsotel transmissions from Troru Tsenam.

166 See Saxer 2013, Gerke 2013. 
Dr Sonam Rinchen, Dr Pema Dorje, Dr Namgyal Tsering and other Tibetan physicians who patiently answered my numerous questions. Special thanks go to Gen Rinpoche Lozang Tenzin Rakdo from the Central University of Tibetan Studies (CUTS) in Sarnath for providing important pieces of the puzzle, and to Tashi Tsering at the Amnye Machen Institute in Dharamsala for valuable literature, critical comments, and his ongoing support during this project. I am also grateful to Robbie Barnett, Tawni Tidwell, and Stacey van Vleet for stimulating discussions and comments, and Theresia Hofer, Dagmar Wujastyk, and two anonymous reviewers for critical feed-back. And, finally, many thanks to my research assistant Tenzin Choezom.

\section{Bibliography}

Avedon, John F. (1997): In Exile from the Land of Snows: The Definitive Account of the Dalai Lama and Tibet Since the Chinese Conquest. New York: Harper Perennial.

Cascardi, Anthony J. (1984): “Remembering”. The Review of Metaphysics 38: 275-302.

Chödrak, Tenzin (1994): Ganzheitlich Leben und Heilen. Der Leibarzt des Dalai Lama über Vorbeugung und Therapie von Krankheiten. Freiburg, Basel, Wien: Herder Verlag.

Chödrak, Tenzin (2005): Im Dienst des Dalai Lama: Die Erinnerungen seines Leibarztes Tenzin Chödrak. Augsburg: Weltbild.

Chödrak, Tenzin/G. van Grasdorff (1999): Im Palast des Regenbogens. Der Leibarzt des Dalai Lamas erinnert sich. Frankfurt a. M., Leipzig: Insel Verlag.

Chödrak, Tenzin/G. van Grasdorff (2000): The Rainbow Palace. A Harrowing Spiritual Memoir. London/New York: Bantam Books.

Choelothar (Chos lo thar) (2000): 'Gro phan sman rtsis khang gi gdan rabs dri med shel gyi me long. Dharamsala: Bod gzhung sman rtsis khang.

Covill, Linda/Roesler, Ulrike/Shaw, Sarah (eds.) (2010): Lives Lived, Lives Imagined: Biography in the Buddhist Traditions. Somerville MA, USA: Wisdom Publications.

Czaja, Olaf (2013): "On the history of refining mercury in Tibetan medicine”. Mercury in Ayurveda and Tibetan Medicine. Special Issue of Asian Medicine: Tradition and Modernity 8.1: 75-105.

Dawa Ridak (2003): Bod kyi gso ba rig pa las sman rdzas sbyor bzo'i lag len gsang sgo 'byed pa'i lde mig. Delhi: Rig Drag Publications.

Dhondup Wangyal Khangkyil (Don grub dbang rgyal Khang dkyil) (2008): Ma bcos drang gtam sna ba'i bdud rtsi. Kathmandu: Darmakosha Press.

Fjeld, Heidi/Hofer, Theresia (2010-2011): “Women and Gender in Tibetan Medicine”. Asian Medicine: Tradition and Modernity 6.2: 175-216.

Garrett, Frances (2009). “Eating Letters in the Tibetan Treasure Tradition”. Journal of the International Association of Buddhist Studies 32: 85-114.

Gerke, Barbara (2012): "Introduction: Challenges of Translating Tibetan Medical Texts and Medical Histories”. In: Wurzeltantra und Tantra der Erklärungen. Aus "Die Vier Tantra der Tibetischen Medizin". Edited by Florian Ploberger. Schiedlberg, Austria: Bacopa Verlag, 17-29. 
Gerke, Barbara (2013): “The Social Life of Tsotel: Processing Mercury in Contemporary Tibetan Medicine”. Mercury in Ayurveda and Tibetan Medicine. Special Issue of Asian Medicine: Tradition and Modernity 8.1: 120-152.

Gerke, Barbara (2015): “The Poison of Touch: Tracing Mercurial Treatments of Syphilis in Tibet”. Social History of Medicine 28.3: 532-554.

Gerke, Barbara (in press). "Buddhist Healing and Taming in Tibet: Ritualised Pharmacology”. In: Oxford Handbook of Contemporary Buddhism. Edited by Michael Jerryson. Oxford: Oxford University Press.

Gerl, Robert/Aschoff, Jürgen (2005): Der Tschagpori in Lhasa: Medizinhochschule und Kloster. Ulm/Donau: Fabri Verlag.

Gyatso, Janet (1998): Apparitions of the Self: The Secret Autobiographies of a Tibetan Visionary. Princeton NJ: Princeton University Press.

Henrion-Dourcy, Isabelle (2013): “A Look at the Margins: Autobiographical Writing in Tibetan in the People's Republic of China”. In: Writing Lives in China, 1600-2010. Edited by M.

Dryburgh and S. Dauncey. Basingstoke: Palgrave Macmillan, 206-235.

Hofer, Theresia (2011): Tibetan Medicine on the Margins: Twentieth Century Transformations of the Traditions of Sowa Rigpa in Central Tibet. Ph.D. thesis, University College London.

Hofer, Theresia (in preparation): Tibetan Medicine on the Margins: Memory, Agency and Socialist Reforms.

Holmes, Ken (1995): “Portrait of a Tibetan Doctor: Khenpo Troru Tsenam”. In: Oriental Medicine: An Illustrated Guide to the Asian Arts of Healing. Edited by Jan Van Alphen and Anthony Aris. London: Serindia, 144-145.

Holmes-Tagchungdarpa, Amy (2014): The Social Life of Tibetan Biography: Textuality, Community, and Authority in the Lineage of Tokden Shakya Shri (Studies in Modern Tibetan (ulture). Plymouth: Lexington Books.

Hsu, Elisabeth (1999): The Transmission of Chinese Medicine. Cambridge: Cambridge University Press.

Jacoby, Sarah H. (2014). Love and Liberation: Autobiographical Writings of the Tibetan Buddhist Visionary Sera Khandro. New York: Columbia University Press.

Jampa Trinlé (Byams pa 'phrin las) (1991): Gangs ljongs gso rig bstan pa'i nyin byed rim byon gyi rnam thar phyogs bsgrigs. Dharamsala: Tibetan Medical \& Astro Institute.

Jampa Trinlé (Byams pa 'phrin las) (2000 [1990]): Gangs ljongs gso rig bstan pa'i nyin byed rim byon gyi rnam thar phyogs bsgrigs. Pe cin: Mi rigs dpe skrun khang.

Jampa Trinlé (Byams pa 'phrin las) (2006): Mkhas dbang byams pa 'phrin las mchog gi bod lugs gso rig gi dran gsos gtam rna ba'i bcud len. Pe cin: Mi rigs dpe skrun khang.

Janes, Craig R. (1995): “The Transformations of Tibetan Medicine”. Medical Anthropology Quarterly 9: 6-39.

Kilty, Gavin (2010): A Mirror of Beryl: Historical Introduction to Tibetan Medicine. Boston, MA: Wisdom Publications.

Kloos, Stephan (2010): Tibetan Medicine in Exile: The Ethics, Politics, and Science of Cultural Survival. Ph.D. thesis, University of California San Francisco and Berkeley.

Kloos, Stephan (2012): “Die Alchemie exil-tibetischer Identität. Anmerkungen zur pharmazeutischen und politischen Wirksamkeit tibetischer Pillen". Curare 35: 197-207.

Lozang Lodrö (Lab phan 'dum Blo bzang blo gros) (2006): Gnas Inga rig pa'i pandi ta mkhan chen khro ru tshe rnam mchog gi rnam thar baidūrya sngon po'i rang mdangs (= Mkhan chen khro ru tshe rnam gyi rnam thar; The biography of the great Troru Tsenam, professor 
and pundit of the five sciences: The self-radiant blue beryl), Pe cin: Krung go'i bod rig pa dpe skrun khang.

Li, Brenda W. L. (2011): A critical study of the life of the thirteenth-century Tibetan monk $U$ rgyan pa Rin chen dpal based on his biographies. DPhil thesis, Oxford University.

McGranahan, Carol (2002): “Sa sPang mda' gNam sPang mda': Murder, History, and Social Politics in 1920s Lhasa”. In: Khams pa Local Histories: Visions of People, Place, and Authority. Edited by Lawrence Epstein. Leiden: Brill Academic Publishers, 103-126.

Men-Tsee-Khang (Oct-Dec 2011): “Successful Completion of Tsothal”. Men-Tsee-Khang News Letter 23: 4-6.

Needham, Joseph/Ho, Ping-Yu/Lu, Gwei-Djen (1976). Science and Civilization in China. Volume 5. Part 3: Spagyrical Discovery and Invention: Historical Survey from Cinnabar Elixirs to Synthetic Insulin. Cambridge: Cambridge University Press.

Pasang Yontan Arya (Pa sangs yon tan) (1988): Bod kyi gso ba rig pa'i lo rgyus kyi bang mdzod g.yu thog bla ma dran pa'i pho nya. Leh, Ladakh: Yuthok Institute of Tibetan Medicine.

Penny, Benjamin (ed.) (2002): Religion and Biography in China and Tibet. Richmond/Surrey, UK: Curzon Press.

Reichle, Franz (1995): Das Wissen Vom Heilen. Documentary Film, 93 min, T\&C Film, Zürich. Saxer, Martin (2013): Manufacturing Tibetan Medicine: The Creation of an Industry and the Moral Economy of Tibetanness. Oxford/New York: Berghahn Books.

Simioli, Carmen (2013): "Alchemical Gold and the Pursuit of the Mercurial Elixir: An Analysis of Two Alchemical Treatises from the Tibetan Buddhist Canon". Mercury in Ayurveda and Tibetan Medicine. Special Issue of Asian Medicine: Tradition and Modernity. 8.1: 41-73.

Sonam Bakdrö (Bsod nams bag dros) (2006): Dngul chu'i byung ba spyi dang bye brag btso bkru rig pa'i lag len rgyas par bkral ba mkhas grub ratna shi'i dgongs rgyan. Lha sa: Bod ljongs mi dmangs dpe skrun khang.

Sonam Oeser (Bsod nams 'od zer) (1997): Grub chen u rgyan pa'i rnam thar. Lha sa: Bod ljongs bod yig dpe rnying dpe skrun khang.

Sonam Rinchen (E pa Bsod nams rin chen) (2000): 'Tsho mdzad slob dpon rnam gsum gyi mdzad 'phrin gnad bsdus skal ldan bu slob dgyes pa'i snying gtam (Heart advice inspiring fortunate disciples: Essential points of the good deeds of three master physicians). Dharamsala: Men-Tsee-Khang.

Sonam Rinchen (E pa Bsod nams rin chen) (2009): Bod kyi srol rgyun sman rtsis rig pa'i dpyad yig mu tig phreng mdzes. Dharamsala: Library of Tibetan Works \& Archives.

Stephens, Karin/Tsarong, Jigme (Fall/Winter 1992): “Interview with Amchi Lobsang Tsultrim”. SMan-rTsis Journal 1.2: 8-14.

Tashi Tsering (Bkra shis tshe ring) (ed.) (1986): Rin chen dinul chu sbyor sde phyogs bsdebs. Collected Works on Mercury Formulations (Rasasiddhiśāstra) by 'Ju Mi-Pham, Bla-sman Orgyan bstan-'dzin, Sde-dge drun்-yig Guru-'phel, Kon-sprul Yon-tan rgya-mtsho. Reproduced from rare manuscripts and Sde-dge woodblocks from the library of Late Dr. Jamyang Tashi, Dr. Tenzin Chodrak, and Dr. Lobsang Tashi. Dharamsala: Library of Tibetan Works and Archives.

Tashi Tsering (Bkra shis tshe ring) (2015): "Looking back at Bla sman Mkhyen rab nor bu: A biographical note and brief discussion of his works". In: Tibetan \& Himalayan Healing. An Anthology for Anthony Aris. Edited by Charles Ramble and Ulrike Roesler. Kathmandu: Vajra Publications, 689-718. 
Thubten Phuntsok (Thub bstan phun tshogs). (1994). "Khro ru mkhan po tshe rnam mchog gi rnam thar mdor bsdus". Mi rigs dus deb (National Minorities) 1: 28-36.

Thubten Tsering (Thub bstan tshe ring) (1986): “Gangs ljongs sman pa’i grong khyer lcags ri 'gro phan rig byed gling gi byung rabs brjod pa gsal pa'i sgron me”. In: Bod kyi sman rtsis ched rtsom phyogs bsdus. Lha sa: Bod ljongs mi dmangs dpe skrun khang, 148-181.

Tokarska-Bakir, Joanna (2000): "Naive Sensualism, Docta Ignorantia. Tibetan Liberation through the Senses". Numen 47: 69-112.

Troru Tsenam (Khro ru tshe rnam) (2001): Gso rig rgyud bzhi'i 'grel chen drang srong zhal lung, 6 vols. Chengdu: Si khron mi rigs dpe skrun khang. Vol. 1.

Trouillot, Michel-Rolph (1995): Silencing the Past: Power and the Production of History. Boston: Beacon Press.

Van Vleet, Stacey (2010-2011): “Children's Healthcare and Astrology in the Nurturing of a Central Tibetan Nation-State, 1916-24”. Asian Medicine: Tradition and Modernity 6.1: 348-386.

Vostrikov, Andrei Ivanovich (1970): Tibetan Historical Literature. Calcutta: R. D. Press.

Willis, Janice Dean (2009): “On the nature of rNam-thar: Early dGe-lugs-pa Siddha biographies". In: Soundings in Tibetan Civilization. Edited by Barbara N. Aziz and Matthew Kapstein. Kathmandu: Vajra Publications, 304-319.

Wujastyk, Dagmar (2013): "Perfect medicine: mercury in Sanskrit medical literature". Mercury in Ayurveda and Tibetan Medicine. Special Issue of Asian Medicine: Tradition and Modernity 8.1: $15-40$.

Yeshe Gonpo (Ye she mgon po) 2005: "Rin chen btso thal gyi man ngag brgyud spel byed mkhan - dkar mdzes khul gyi bod sman 'bum rams pa tham kha ngag dbang rgya mtsho'i mdzad rjes bkod pa". Gangs dkar ri bo 1: 40-43. 